\title{
Status ketersediaan makanan dan status gizi ibu sebagai faktor risiko kegemukan pada anak prasekolah
}

\author{
Home food availability status and maternal obesity as risk factors of obesity in preschool children
}

\author{
${ }^{1}$ Program Studi Ilmu Gizi, Fakultas Ilmu Kesehatan Universitas Respati Yogyakarta \\ ${ }^{2}$ Department Ilmu Penyakit Dalam, Rumah Sakit Umum Pusat Dr. Sardjito \\ ${ }^{3}$ Jurusan Gizi Politeknik Kesehatan Kementerian Kesehatan Yogyakarta
}

Yunita Indah Prasetyaningrum ${ }^{1}$, Nyoman Kertia ${ }^{2}$, I Made Alit Gunawan ${ }^{3}$

\begin{abstract}
Background: Childhood obesity is a strong predictor of adult obesity incidence and can increase risk factors for getting chronic diseases. The causes of obesity are multifactor, determined by genetic and food environment changes. Risk factors believed to be the cause of obesity are home food availability status and maternal obesity. Objective: To analyze the risk of home food availability status and maternal obesity to obesity in preschool children aged 3-5 years. Method: This study was a matched case-control study. Case of this study was obese preschool children (Z-score WHZ > 2 SD) and control of this study was non-obese preschool children (Z-score WHZ -2 $\leq \mathrm{SD} \leq 2$ ). Control group was taken by an age and gender matching with the case group. Based on the nutritional status screening result of 53 early childhood education (ECD) schools on 13 sub-districts in Kota Yogyakarta, there were 101 obese children and 101 non-obese children. Those schools were chosen by cluster sampling method and PPS (Probability Proportional to Size). Besides, information about home food availability status and maternal obesity was collected using questionnaire. The data were analyzed using $\mathrm{McNemar}$ test and conditional logistic regression. Results: Home food availability status $(\mathrm{OR}=1.85$; $\mathrm{p}=0.03 ; 95 \% \mathrm{CI}=1.08-3.16)$ and maternal obesity $(\mathrm{OR}=2.5 ; \mathrm{p}=0.003 ; 95 \% \mathrm{CI}=1.37-4.55)$ were the most dominant risk factor related to the incidence of obesity in preschool children aged 3-5 years. Conclusion: Home food availability status and maternal obesity significantly increase the risk for getting obese in preschool children aged 3-5 years.
\end{abstract}

KEYWORDS: home food availability status; maternal obesity; obesity; preschool

\begin{abstract}
ABSTRAK
Latar belakang: Kota Yogyakarta merupakan salah kota dengan prevalensi kegemukan pada balita cukup tinggi yaitu 8,98\%. Kegemukan pada anak prasekolah menjadi prediktor kuat terjadinya obesitas di usia dewasa serta meningkatkan risiko beberapa penyakit degeneratif. Penyebab kegemukan bersifat multifaktor, ditentukan oleh faktor genetik dan perubahan lingkungan makanan. Faktor risiko yang dipercaya menyebabkan kegemukan pada anak adalah status ketersediaan makanan dan status gizi ibu. Tujuan: Menganalisis besar risiko status ketersediaan makanan dan status gizi ibu terhadap kegemukan pada anak prasekolah usia 3-5 tahun. Metode: Penelitian ini merupakan penelitian matched case control. Kasus adalah anak prasekolah yang gemuk (Z-score $>2$ SD), kontrol adalah anak prasekolah gizi normal (Z-score $-2 \leq \mathrm{SD} \leq 2$ ). Sebanyak 101 anak gemuk dan 101 anak status gizi normal diperoleh berdasarkan hasil skrining status gizi pada 53 sekolah PAUD dari 13 kecamatan di Kota Yogyakarta berpartisipasi dalam penelitian ini. Teknik pengambilan sampel sekolah dengan metode cluster sampling dan Probability Proportional to Size (PPS). Kontrol diambil melalui proses matching usia dan jenis kelamin dengan kasus. Informasi data ketersediaan makanan dan status gizi ibu dikumpulkan menggunakan kuesioner. Analisis data menggunakan uji statistik McNemar dan kondisional regresi logistik. Hasil: Status ketersediaan makanan $(\mathrm{OR}=1,85 ; \mathrm{p}=0,03 ; 95 \% \mathrm{CI}=1,08-3,16)$ dan status gizi ibu $(\mathrm{OR}=2,5 ; \mathrm{p}=0,003 ; 95 \%$ $\mathrm{CI}=1,37-4,55)$ merupakan faktor risiko dominan penyebab kegemukan pada anak prasekolah usia 3-5 tahun. Simpulan: Status ketersediaan makanan dan status gizi ibu berhubungan signifikan meningkatkan peluang risiko kegemukan pada anak prasekolah usia 3-5 tahun.
\end{abstract}

KATA KUNCI: status ketersediaan makanan; status gizi ibu; kegemukan; prasekolah

Korespondensi: Yunita Indah Prasetyaningrum, Program Studi Ilmu Gizi, Fakultas Ilmu Kesehatan Universitas Respati Yogyakarta, Jl. Raya Tajem km 1,5 Maguwoharjo, Depok, Sleman, Yogyakarta,e-mail: yunita_indah.nutrition@mail.ugm.ac.id 


\section{PENDAHULUAN}

Kegemukan pada anak merupakan prediktor kuat kejadian obesitas di usia dewasa $(1,2)$ serta meningkatkan risiko terjadinya beberapa penyakit, seperti diabetes melitus tipe 2 (1), hipertensi (3), dislipidemia, dan penurunan kualitas hidup (4). Riset Kesehatan Dasar (Riskesdas) menyatakan prevalensi kegemukan pada anak secara nasional mengalami peningkatan dari tahun 2007 (12,2\%), 2010 (13,3\%) hingga tahun 2013 (18,8\%) (5). Sementara itu, Kota Yogyakarta menjadi salah satu kota dengan prevalensi kegemukan pada anak cukup tinggi yaitu sebesar 8,98\% (6).

Penyebab kegemukan bersifat multifaktor, meliputi faktor genetik, lingkungan, dan perilaku (7). Kegemukan terjadi akibat interaksi faktor genetik dan kontribusi perubahan lingkungan (8). Kegemukan pada ibu merupakan prediktor kuat perkembangan anak menjadi gemuk (9). Kejadian kegemukan pada anak berhubungan signifikan dengan sifat yang dibawa ibu terkait berat badan anak dan peran ibu dalam proses pengasuhan (10). Sementara itu, lingkungan yang dianggap paling berpengaruh terhadap asupan makan terkait obesitas pada anak adalah home food environment $(11,12)$ karena sebagian besar (dua per tiga) makanan dalam sehari yang dikonsumsi anak berasal dari rumah $(13,14)$. Salah satu aspek penyusun home food environment yang berkaitan erat dengan status berat badan anak prasekolah (15) adalah ketersediaan makanan di rumah (16). Asupan makan anak berhubungan positif dengan ketersediaan makanan sehat (sayuran dan buah) ataupun makanan tidak sehat di rumah (makanan tinggi energi minuman manis, soft drink) (17-20). Penelitian ini bertujuan untuk mengetahui status ketersediaan makanan di rumah dan status gizi ibu sebagai faktor risiko kegemukan pada anak prasekolah di Kota Yogyakarta.

\section{BAHAN DAN METODE}

Jenis penelitian yang akan dilaksanakan adalah observasional dengan rancangan penelitian matched case control. Penelitian dilaksanakan pada bulan Juni hingga Oktober 2015. Penelitian dilakukan di sekolah Pendidikan Anak Usia Dini (PAUD) seperti tempat penitipan anak (TPA) dan kelompok bermain (KB) yang berada di wilayah kerja Dinas Pendidikan Kota Yogyakarta. Penelitian dilakukan setelah mendapatkan surat izin penelitian dengan nomor KE/FK/747/EC/2015 dari Komisi Etik, Fakultas Kedokteran Universitas Gadjah Mada. Sampel penelitian adalah anak berusia 3-5 tahun yang bersekolah PAUD di Kota Yogyakarta. Kasus adalah anak prasekolah yang gemuk (Z-score BB/TB >2 SD) dengan kriteria inklusi berusia 3-5 tahun, bersekolah PAUD di Kota Yogyakarta, tinggal serumah dengan ibu, dan bersedia mengikuti penelitian hingga selesai. Kriteria eksklusinya adalah anak berkebutuhan khusus dan anak yang bersekolah di sekolah PAUD full day. Kontrol adalah anak prasekolah gizi normal (Z-score BB/TB $-2 \leq \mathrm{SD} \leq 2$ ) yang mengalami proses matching usia dan jenis kelamin dengan kasus.

Perhitungan besar sampel menggunakan rumus untuk penelitian kasus kontrol berpasangan (21) dengan tingkat kepercayaan 95\% ( $\mathrm{Z} \alpha)$; Z $\beta$ sebesar 0,842 ; dan odds ratio (OR) sebesar 2. Jumlah sampel minimal yang harus dipenuhi adalah 184 orang (92 orang kelompok kasus dan 92 orang kelompok kontrol). Subjek penelitian sebanyak 101 anak gemuk dan 101 anak status gizi normal diperoleh berdasarkan hasil skrining status gizi di 53 sekolah PAUD dari 13 kecamatan di Kota Yogyakarta. Pengambilan sampel dengan teknik multistage sampling sedangkan teknik pengambilan sampel sekolah dengan metode cluster sampling danProbability Proportional to Size (PPS). Variabel bebas dalam penelitian ini adalah status ketersediaan makanan dan status gizi ibu sedangkan variabel tergantung adalah kegemukan pada anak prasekolah. Sementara itu, variabel luar yang berpotensi mempengaruhi kegemukan turut diperhitungkan, seperti pendidikan orangtua dan pendapatan keluarga.

Status kegemukan diukur menggunakan standar berat badan menurut tinggi badan anak usia 24-60 bulan menggunakan World Health Organization (WHO) Anthro dan mengacu pada Kementrian Kesehatan Indonesia. Kriteria status kegemukan dibedakan menjadi 2 yaitu gemuk jika nilai z-score $>2$ dan normal jika z-score $\geq-2$ $\mathrm{SD}$ sampai $\leq 2 \mathrm{SD}$ (22). Status ketersediaan makanan menilai ketersediaan makanan makanan sehat (sayuran dan buah-buahan) dan makanan tidak sehat (makanan tinggi energi dan kalori) yang biasa ada dan disimpan di rumah serta dinyatakan dalam skala $(16,23)$. Dikatakan status tidak sehat jika jumlah skor makanan tidak sehat yang tersedia lebih banyak dibandingkan skor makanan 
sehat (20). Dikategorikan status tidak sehat jika skor kurang dari skala 2 dan dikatakan sehat jika nilai skor lebih dari atau sama dengan skala 2. Informasi data status ketersediaan makanan dikumpulkan menggunakan kuesioner Home Enviromental Survey (HES) dan Healthy Home Survey (HHS) yang telah dimodifikasi melalui wawancara. Sementara itu, berat badan dan tinggi badan ibu ditanyakan saat wawancara.

Pendidikan orangtua dinilai dari pendidikan formal terakhir yang pernah ditempuh oleh orangtua yang dikategorikan tinggi jika menempuh pendidikan lulus SMA dan diatasnya sedangkan pendidikan rendah jika menempuh pendidikan di bawah tingkat SMA(UU No. 20 Tahun 2003). Pendapatan keluarga dilihat dari pendapatan keluarga dalam sebulan dan dikategorikan rendah jika pendapatan sebulan lebih kecil dari nilai upah minimum regional (UMR) Kota Yogyakarta yaitu Rp1.302.500 (24). Penilaian status gizi ibu menggunakan perhitungan indeks massa tubuh (IMT) dilakukan pada saat penelitian yang dibedakan menjadi dua kategori, yaitu gemuk (IMT $>25$ $\mathrm{kg} / \mathrm{m}^{2}$ ) dan tidak gemuk (IMT $\left.\leq 25 \mathrm{~kg} / \mathrm{m}^{2}\right)$.

Kuesioner yang akan digunakan pada pengumpulan data terlebih dahulu dilakukan translation dan back translation oleh penerjemah berlatar belakang pendidikan
Sastra Inggris. Peneliti juga melakukan focus group discussion (FGD) untuk mengetahui variasi bahan makanan yang biasa tersedia bagi anak prasekolah, khususnya yang tinggal di Kota Yogyakarta. Pelaksanaan uji validasi kuesioner dilakukan pada 29 ibu yang memiliki anak berusia 3-5 tahun. Uji validasi kuesioner status ketersediaan makanan memiliki nilai cronbach alpha sebesar 0,85 (baik digunakan). Pada alat ukur tinggi badan dilakukan uji reliabilitas intra/inter observer dengan hasil sangat baik yaitu 97,76-99,79\%. Sementara itu, uji korelasi antar dua timbangan berat badan memiliki nilai $r=0,934$ (sangat baik).

Pengumpulan data dilakukan oleh 6 orang enumerator dengan latar belakang pendidikan S1 Gizi yang telah mendapatkan pelatihan sebelumnya. Data yang telah terkumpul akan dianalisis univariat untuk melihat distribusi data subjek. Analisis bivariat Chi-Square untuk melihat perbedaan karakteristik antar kedua kelompok (kasus-kontrol) serta uji McNemar untuk menentukan odds ratio setiap variabel yang diduga sebagai faktor risiko kegemukan. Analisis multivariat dilakukan dengan uji regresi logistik kondisional untuk mendapatkan faktor risiko dominan yang menyebabkan kegemukan pada anak prasekolah usia 3-5 tahun.

Tabel 1. Karakteristik subjek penelitian

\begin{tabular}{|c|c|c|c|c|c|c|c|}
\hline \multirow[t]{2}{*}{ Variabel } & \multicolumn{2}{|c|}{$\begin{array}{c}\text { Kasus } \\
(\mathrm{n}=\mathbf{1 0 1})\end{array}$} & \multicolumn{2}{|c|}{$\begin{array}{c}\text { Kotrol } \\
(\mathrm{n}=101)\end{array}$} & \multirow[t]{2}{*}{$\mathbf{X}^{2}$} & \multirow[t]{2}{*}{ OR $(95 \% C l)$} & \multirow[t]{2}{*}{$\mathbf{p}$} \\
\hline & $\mathbf{n}$ & $\%$ & $\mathbf{n}$ & $\%$ & & & \\
\hline \multicolumn{8}{|l|}{ Karakteristik anak } \\
\hline \multicolumn{8}{|l|}{ Jenis kelamin ${ }^{\mathrm{a}}$} \\
\hline Laki-laki & 54 & 53,47 & 54 & 53,47 & 0,00 & & $1,00^{1}$ \\
\hline Perempuan & 47 & 46,53 & 47 & 46,53 & & & \\
\hline \multicolumn{8}{|l|}{ Usia anak (tahun) ${ }^{\mathrm{a}}$} \\
\hline 3 & 34 & 33,66 & 34 & 33,66 & 1,03 & & $0,59^{1}$ \\
\hline 4 & 64 & 63,37 & 66 & 66,35 & & & \\
\hline 5 & 3 & 2,97 & 1 & 0,99 & & & \\
\hline \multicolumn{8}{|c|}{ Karakteristik orangtua } \\
\hline \multicolumn{8}{|c|}{ Pendidikan ibu } \\
\hline Tinggi & 69 & 68,32 & 64 & 63,37 & 0,55 & 0,80 & $0,46^{1}$ \\
\hline Rendah & 32 & 31,68 & 37 & 36,63 & & $(0,429-1,496)$ & \\
\hline \multicolumn{8}{|l|}{ Pendidikan ayah } \\
\hline Tinggi & 62 & 62,00 & 63 & 62,38 & 0,00 & 1,02 & $0,96^{1}$ \\
\hline Rendah & 38 & 38,00 & 38 & 37,62 & & $(0,553-1,870)$ & \\
\hline \multicolumn{8}{|l|}{ Pendapatan keluarga } \\
\hline Tinggi & 94 & 93,07 & 95 & 94,06 & 0,08 & 1,18 & $0,77^{1}$ \\
\hline Rendah & 7 & 6,93 & 6 & 5,94 & & $(0,325-4,413)$ & \\
\hline
\end{tabular}

$\mathrm{a}=$ Variabel matching kelompok kasus dan kontrol; ${ }^{1=} \mathrm{Uji}$ Chi-Square 
HASIL

Berdasarkan skrining status gizi diperoleh 200 anak berstatus gizi gemuk (11,57\%), 1.460 anak berstatus gizi normal $(84,49 \%)$, dan 68 anak berstatus gizi kurus $(3,94 \%)$. Sebagian besar anak yang gemuk berjenis kelamin laki-laki dan berusia 4 tahun. Jumlah subjek dalam penelitian ini sebanyak 202 anak prasekolah usia 3-5 tahun. Terdiri dari 101 subjek berstatus gizi gemuk dan 101 subjek berstatus gizi normal. Sebagian besar ibu dari subjek penelitian berusia 31-40 tahun. Berdasarkan uji Chi-Square menunjukkan tidak ada perbedaan

Tabel 2. Status ketersediaan makanan dan status gizi pada kelompok kasus dan kontrol

\begin{tabular}{lcccc}
\hline \multirow{2}{*}{ Variabel } & \multicolumn{2}{c}{ Kasus } & \multicolumn{2}{c}{ Kontrol } \\
\cline { 2 - 5 } & $\mathbf{n}$ & $\mathbf{\%}$ & $\mathbf{n}$ & $\mathbf{\%}$ \\
\hline $\begin{array}{l}\text { Status ketersediaan makanan } \\
\quad \text { Tidak Sehat }\end{array}$ & 50 & 49,50 & 33 & 32,67 \\
$\quad$ Sehat & 51 & 50,50 & 68 & 67,33 \\
Status gizi ibu & & & & \\
$\quad$ Gemuk & 53 & 52,48 & 30 & 29,70 \\
$\quad$ Normal & 48 & 47,52 & 71 & 70,30 \\
\hline
\end{tabular}

signifikan antara pendidikan orangtua dan pendapatan keluarga dengan kegemukan $(\mathrm{p}>0,05)$ (Tabel 1).

Pada Tabel 2 menunjukkan bahwa subjek penelitian yang status ketersediaan makanan dirumahnya tergolong tidak sehat lebih banyak ditemui pada kelompok kasus (50 orang atau 49,50\%) dibandingkan kelompok kontrol (33 orang atau $32,67 \%$ ). Ibu dengan status gizi gemuk lebih banyak terdapat pada kelompok kasus (53 orang atau 52,48\%) dibandingkan kelompok kontrol (30 orang atau $29,70 \%$ ).

Berdasarkan hasil uji McNemar (Tabel 3) subjek penelitian yang status ketersediaan makanannya tidak sehat berisiko 1,85 kali menjadi gemuk dibandingkan subjek penelitian yang status ketersediaan makanannya sehat. Hasil uji McNemar juga menunjukkan bahwa subjek yang ibunya berstatus gemuk memiliki odds ratio sebesar 2,5 ( $\mathrm{p}=0,003 ; 95 \% \mathrm{CI}=1,37-4,55)$. Artinya, subjek yang memiliki ibu berstatus gizi gemuk memiliki peluang 2,5 kali lebih tinggi untuk mengalami kegemukan.

Analisis multivariat dengan uji kondisional regresi logistik menggunakan pemodelan yang membandingkan

Tabel 3. Analisis McNemar status ketersediaan makanan dan status gizi ibu terhadap kegemukan pada anak prasekolah usia 3-5 tahun

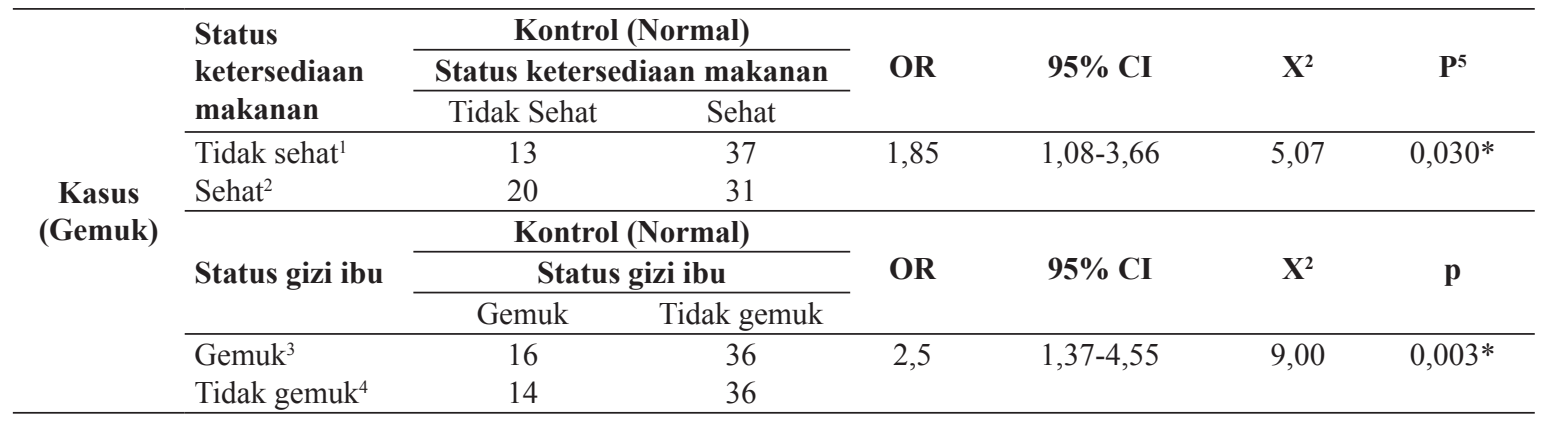

${ }^{1}$ Tidak sehat: < skala $2 ;{ }^{2}$ Sehat: $\geq$ skala $2 ;{ }^{3}$ Gemuk: IMT $>25 \mathrm{~kg} / \mathrm{m}^{2} ;{ }^{4}$ Tidak Gemuk: IMT $\leq 25 \mathrm{~kg} / \mathrm{m}^{2} ;{ }^{5}$ Mc Nemar; ${ }^{*}$ signifikan $(\mathrm{p}<0,05)$

Tabel 4. Faktor yang berpengaruh dominan terhadap kejadian kegemukan berdasarkan model kondisional regresi logistic

\begin{tabular}{llccc}
\hline & \multicolumn{1}{c}{ Model dan Variabel } & OR $\mathbf{( 9 5 \%}$ CI) & $\mathbf{p}^{\mathbf{1}}$ & $\mathbf{R}^{\mathbf{2}}$ \\
\hline Model 1 & Status ketersediaan makanan & $2,22(1,19-4,11)$ & $0,011^{*}$ & \\
& Status gizi ibu & $3,45(1,74-6,82)$ & $0,000^{*}$ & 0,1521 \\
& Pendidikan ibu & $0,54(0,23-1,27)$ & 0,157 & \\
& Pendidikan ayah & $1,29(0,59-2,85)$ & 0,521 & \\
& Pendapatan keluarga & $0,69(0,16-2,98)$ & 0,622 & \\
\hline Model 2 & Status ketersediaan makanan & $2,10(1,16-3,79)$ & $0,014^{*}$ & 0,1230 \\
& Status gizi ibu & $2,91(1,53-5,59)$ & $0,001^{*}$ & \\
\hline
\end{tabular}

${ }^{1}$ Uji kondisional regresi logistik; *=signifikan $(\mathrm{p}<0,05)$ 
nilai OR status ketersediaan makanan dan status gizi ibu dengan variabel luar (pendidikan orangtua, pendapatan keluarga) secara bersama-sama. Model 1 memperlihatkan bahwa interaksi variabel status ketersediaan dan beberapa variabel luar mampu memprediksi kejadian kegemukan pada anak prasekolah usia 3-5 tahun sebesar 15,21\%. Model 2 yang memperlihatkan status ketersediaan makanan dan status gizi ibu menjadi faktor paling dominan yang menyebabkan kegemukan pada anak prasekolah usia 3-5 tahun dengan kemampuan memprediksi kejadian kegemukan sebesar 12,30\% (Tabel 4).

\section{BAHASAN}

Tahap skrining pada penelitian ini mampu menunjukkan prevalensi kegemukan pada anak prasekolah usia 3-5 tahun di Kota Yogyakarta sebesar 11,57\%, angka yang lebih tinggi dibandingkan data Riskesdas tahun 2014 (6). Sesuai dengan yang diungkapkan oleh peneliti sebelumnya (25) bahwa peningkatan prevalensi kegemukan pada anak usia kurang dari tahun akan terjadi hingga tahun 2020, baik di negara maju atau negara berkembang (26-27). Berdasarkan hasil analisis diketahui tidak ada perbedaan karakteristik subjek penelitian berdasarkan pendidikan orangtua dan pendapatan keluarga karena sebagian besar subjek tinggal bersama orangtua dengan tingkat pendidikan tinggi dan pengategorian pendapatan hanya berdasarkan UMR Kota Yogyakarta sehingga sebagian besar pendapatan keluarga subjek masuk ke dalam kategori pendapatan tinggi.

Penelitian ini menemukan $41,09 \%$ subjek penelitian memiliki status ketersediaan makanan kategori tidak sehat. Pada kelompok kasus lebih banyak ditemui subjek yang memiliki status ketersediaan makanan kategori tidak sehat sedangkan status ketersediaan makanan kategori sehat lebih banyak pada kelompok kontrol. Hasil analisis menunjukkan hubungan signifikan antara status ketersediaan makanan dengan kejadian kegemukan pada anak prasekolah di Kota Yogyakarta. Penelitian sebelumnya menyatakan anak TK yang tinggal dengan keluarga yang memiliki ketersediaan makanan tidak sehat (minuman manis, makanan ringan asin dan manis) lebih banyak memiliki risiko menjadi gemuk lebih tinggi dibandingkan yang tinggal dengan keluarga yang memiliki ketersediaan makanan tidak sehat lebih sedikit (28). Ketersediaan makanan dapat secara langsung maupun tidak langsung memengaruhi kebiasaan yang terkait dengan berat badan, yaitu melalui kesukaan dan asupan makan. Anak prasekolah yang mengonsumsi lemak berlebih ( $\geq 120 \% \mathrm{AKG}$ ) memiliki risiko 4,23 kali lebih tinggi untuk mengalami kegemukan dibandingkan anak prasekolah yang memiliki asupan lemak dalam jumlah cukup (29). Hasil penelitian di Inggris menyatakan anak prasekolah yang tinggal di lingkungan makan yang obesogenik dapat menurunkan konsumsi sayuran dan buah-buahan serta meningkatkan konsumsi snack tinggi energi dan minuman manis (30). Pasalnya, anak akan belajar untuk menyukai makanan tinggi energi jika sering terpapar (tersedia) makanan tersebut di rumah (31).

Penelitian ini menemukan bahwa kelompok kasus lebih banyak yang tinggal bersama ibu gemuk (53 orang atau 52,48\%) dibandingkan kelompok kontrol (30 orang atau 29,70\%). Hasil analisis menunjukkan bahwa subjek yang tinggal bersama ibu dengan status gizi gemuk memiliki peluang 2,5 kali lebih tinggi untuk mengalami kegemukan. Kegemukan pada ibu merupakan prediktor kuat perkembangan anak menjadi obesitas (32-33). Anak usia 2-6 tahun yang tinggal dengan orangtua gemuk memiliki kemungkinan $14,1 \%(\mathrm{OR}=1,98)$ lebih tinggi menjadi gemuk dibandingkan anak yang tinggal dengan ibu tidak gemuk (34). Kegemukan pada anak berhubungan signifikan dengan sifat yang dibawa oleh ibu terkait berat badan anak dan peran ibu dalam pola pengasuhan $(10,35)$.

Hasil analisis multivariat menunjukkan bahwa faktor dominan penyebab kegemukan pada anak prasekolah adalah status ketersediaan makanan dan status gizi ibu. Kedua variabel tersebut mampu memprediksi kejadian kegemukan pada anak prasekolah 3-5 tahun sebesar $12,30 \%$. Hubungan variabel status ketersediaan makanan dan status gizi ibu terhadap kegemukan anak prasekolah bersifat adiktif yaitu saling meningkatkan odds ratio. Artinya, anak yang tinggal di rumah dengan status ketersediaan makanan tidak sehat dan bersama ibu yang gemuk meningkatkan risiko kegemukan. Beberapa hasil penelitian terdahulu menyatakan bahwa status gizi ibu menjadi pengaruh dominan penyebab kegemukan pada anak $(28,36)$. Karakter keluarga dengan orangtua yang mengalami kegemukan adalah sering membeli dan 
menyediakan makanan tinggi lemak dan karbohidrat $(37,38)$. Sementara itu, berat badan dipengaruhi kuat oleh sifat genetik (39). Hal ini membuktikan bahwa faktor genetik menjadi prediktor kuat kegemukan pada anak dengan mempengaruhi lingkungan makan anak (40).

\section{SIMPULAN DAN SARAN}

Status ketersediaan makanan yang tidak sehat dan ibu yang berstatus gizi gemuk meningkatkan risiko kegemukan pada anak prasekolah usia 3-5 tahun di Kota Yogyakarta. Hal ini membuktikan bahwa faktor genetik menjadi prediktor kuat kegemukan pada anak dengan mempengaruhi lingkungan makan anak. Orangtua sebaiknya menciptakan lingkungan makan di rumah yang sehat dengan lebih sering menyediakan makanan sehat (seperti sayuran dan buah-buahan) dan mengurangi makanan tidak sehat (seperti minuman manis, minuman bersoda, makanan kemasan) untuk menurunkan peluang kejadian kegemukan pada anak prasekolah. Orangtua khususnya ibu sebaiknya memperhatikan status gizinya karena secara langsung menjadi role model yang akan ditiru oleh anak usia prasekolah.

\section{Pernyataan konflik kepentingan}

Penulis menyatakan tidak ada konflik kepentingan dengan pihak-pihak yang terkait dalam penelitian ini.

\section{RUJUKAN}

1. Biro FM, Wien M. Childhood obesity and adult morbidities. Am J Clin Nutr 2010;91(5):1499S-505S.

2. Brisbois TD, Farmer a P, McCargar LJ. Early markers of adult obesity: a review. Obes Rev 2012;13(4):347-67.

3. Saha AK, Sarkar N, Chatterjee T. Health consequences of childhood obesity. Indian J Pediatr 2011;78(11):1349-55.

4. Ebbeling CB, Pawlak DB, Ludwig DS. Childhood obesity: public-health crisis, common sense cure. The Lancet 2002;360(9331):473-482.

5. Badan Penelitian Pengembangan Kesehatan. Laporan hasil riset kesehatan dasar (RISKESDAS) IndonesiaTahun 2013. Jakarta: Departemen Kesehatan Republik Indonesia; 2014.

6. Dinas Kesehatan Provinsi DIY. Rekapitulasi hasil pemantauan status gizi (PSG) balita di Provinsi DIY Tahun 2013. Yogyakarta: Dinas Kesehatan DIY; 2014.
7. Flynn MAT, Mcneil DA, Maloff B, Mutasingwa D, Wu $\mathrm{M}$, Ford C, et al. Reducing obesity and related chronic disease risk in children and youth: a synthesis of evidence with "best practice" recommendations. Obes Rev 2006;7 Suppl 1:7-66.

8. Spiegelman BM, Flier JS. Obesity and the regulation of energy balance. Cell 2001;104:531-43.

9. James KS, Matsangas P, Connelly CD. Childhood obesity risk in overweight mothers :support for screening. ICAN: Infant, Child, \& Adolescent Nutrition 2013;5:375-82.

10. Reilly JJ, Armstrong J, Dorosty AR, Emmett PM, Ness A, Rogers I, et al. Early life risk factors for obesity in childhood: cohort study John. BMJ 2005;330:1357.

11. Campbell KJ, Crawford DA, Salmon J, Carver A, Garnett SP, Baur LA, et al. Associations between the home food environment and obesity-promoting eating behaviors in adolescence. Obesity 2007;15(3):719-30.

12. Rosenkranz RR, Dzewaltowski DA. Model of the home food environment pertaining to childhood obesity. Nutr Rev 2008;66(3):123-40.

13. Adair LS, Popkin BM. Public health and public policy are child eating patterns being transformed globally? Obes Res 2005;13:1281-99.

14. Poti JM, Popkin BM. Trends in energy intake among US Children by eating location and food source, 1977-2006. J Am Diet Assoc 2011;111:1156-64.

15. Lindsay AC, Sussner KM, Kim J, Gortmaker S. The role of parents in preventing childhood obesity. Spring 2006;16(1):169-86.

16. Gattshall ML, Shoup JA, Marshall JA, Crane LA, Estabrooks PA. Validation of a survey instrument to assess home environments for physical activity and healthy eating in overweight children. Int $\mathrm{J}$ Behav Nutr and Phys Act 2008;13:1-13.

17. Cullen KW, Baranowski T, Owens E, Marsh T, Rittenberry L, Moor Cde. Availability, accessibility, and preferences for fruit, $100 \%$ fruit juice, and vegetables influence children's dietary behavior. Health Educ Behav 2003;30:615-26.

18. Grimm GC, Harnack L, Story M. Factors associated with soft drink consumption in school-aged children. J Am Diet Assoc 2004; 104:1244-9.

19. Spurrier, NJ, Magarey AA, Golley R, Curnow F, Sawyer MG. Relationships between the home environment and physical activity and dietary patterns of preschool children: a crosssectional study. Int J Behav Nutr and Phys Act 2008;5:31.

20. Ding D, Sallis JF, Norman GJ, Saelens BE, Harris SK, Kerr J, et al. Community food environment, home food environment, and fruit and vegetable intake of children and adolescents. J Nutr Educ Behav 2012;44(6):634-8.

21. Kasjono HS, Yasril. Teknik sampling untuk penelitian kesehatan. Yogyakarta: Graha Ilmu; 2013. 
22. Direktorat Bina Gizi. Keputusan Menteri Kesehatan Republik Indonesia Tentang Standar Antropometri Penilaian Status Gizi Anak. Jakarta: Kemenkes RI; 2011.

23. Bryant MJ, Ward DS, Hales D, Vaughn A, Tabak RG, Stevens J. Reliability and validity of the healthy home survey: a tool to measure factors within homes hypothesized to relate to overweight in children. Int $\mathrm{J}$ Behav Nutr and Phys Act 2008;5:1-11.

24. Dinas Tenaga Kerja dan Transmigrasi DIY. Upah minimum kabupaten/kota di DIY Tahun 2015. [series online] 2014 [cited 2015 Mar 10]. Available from: URL: http://www. nakertrans.jogjaprov.go.id

25. Onis M De, Blo M, Borghi E. Global prevalence and trends of overweight and obesity among preschool children. Am J Clin Nutr 2010;92:1257-64.

26. Lyu Y, Ouyang F, Ye XY, Zhang J, Lee SK, Li Z. Trends in overweight and obesity among rural preschool children in Southeast China from 1998 to 2005. Public Health 2013;7(38):3-10.

27. Ng M, Fleming T, Robinson M, Thomson B, Graetz N, Margono C, et al. Global, regional, and national prevalence of overweight and obesity in children and adults during $1980-2013$ : a systematic analysis for the Global Burden of Disease Study 2013. Lancet 2014;384:766-81.

28. Arcan C, Hannan PJ, Fulkerson JA, Himes JH, Rock BH, Smyth M, et al. Associations of home food availability, dietary intake, screen time and physical activity with bmi in young American-Indian Children. Public Health Nutr 2012;16(1):146-55.

29. Yutanti WT. Perilaku pemberian makan ibu dan asupan makan sebagai faktor risiko kegemukan pada anak prasekolah di Kota Yogyakarta [Tesis]. Yogyakarta: Fakultas Kedokteran Universitas Gadjah Mada; 2016.

30. Schrempft S, Jaarsveld CHM Van, Fisher A, Wardle J. The obesogenic quality of the home environment : associations with diet, physical activity, TV viewing, and BMI in preschool. PLoS One 2015;10(8):1-17.

31. Haire-Joshu D, Nanney M. Prevention of overweight and obesity in children: influences on the food environment. Diabetes Educ 2002;28(3):415-23.

32. Whitaker RC, Wright J, Pepe MS, Seidel K, Dietz W. Predicting obesity in young adulthood from childhood and parental obesity. J Med 1997;337(13):869-73.

33. García EG, López M-Á, Galera Martínez R, Alias I, Martín González M, Bonillo Perales A, et al. Prevalence of overweight and obesity in children and adolescents aged 2-16 years. Endocrinol Nutr 2013;60(3):121-6.

34. Jiang J, Rosenqvist U, Wang H, Greiner T, Ma Y, Toschke AM. Risk factors for overweight in 2-to 6-year-old children in Beijing, China. Int J Pediatr Obes 2006;1(2):103-8.

35. Strauss RS, Knight J. Influence of the home environment on the development of obesity in children. Pediatrics 1999;103(6):e85.

36. Couch SC, Glanz K, Zhou C, Sallis JF, Saelens BE. Home food environment in relation to children's diet quality and weight status. J Acad of Nutr Diet 2014;114(10):1569-79.

37. Byrd-Bredbenner C, Abbot JM. Differences in food supplies of u.s. households with and without overweight individuals. Appetite 2009;52:479-84.

38. Ihmels MA, Welk GJ, Eisenmann JC, Nusser SM. Development and preliminary validation of a family nutrition and physical activity (fnpa) screening tool. Int J Behav Nutr and Phys Act 2009;6:1-10.

39. Shrewsbury V, Wardle J. Socioeconomic status and adiposity in childhood : a systematic review of crosssectional studies 1990-2005. Obesity 2008;16:275-84.

40. Semmler C, Ashcroft J, Jaarsveld CHM Van, Carnell $\mathrm{S}$, Wardle J. Development of overweight in children in relation to parental weight and socioeconomic status. Obesity 2009;17(4):814-20. 